\title{
Pemodelan basis data untuk laporan penjualan wholesale kendaraan mobil.
}

\author{
Aam Shodiqul Munir ${ }^{1}$, Rifqi Anugrah*2, Nurul Ilma Hasana \\ Kunio $^{3}$, Elisabeth Christina Sari ${ }^{4}$ dan Rizal Sapta Dwi Harjo5 ${ }^{5}$ \\ 1,2,4,5 Program Magister Teknik Informatika Universitas Amikom Yogyakarta \\ JL. Ring Road Utara, Condong Catur, Sleman, Yogyakarta 55283 \\ aamshodiqulmunir;rifqianugrah; nurulilmahk; elisabeth.0436;rizal. 9118 \\ Qstudents.amikom.ac.id
}

\begin{abstract}
Abstrak
GAIKINDO atau Gabungan Industri Kendaraan Bermotor Indonesia adalah sebuah perusahaan atau organisasi nirlaba yang bergerak di bidang industri otomotif. Sebuah perusahaan bisa dikatakan sukses atau tidaknya bisa dilihat dari salah satu sudut pandang iaitu penjualan pada perusahaan tersebut. Penjualan merupakan salah satu hal penting bagi perusahaan karena dapat menunjang pertumbuhan perusahaan. Karena semakin berkembangnya zaman maka persaingan antar perusahaan semakin ketat, perusahaan dituntut untuk lebih kreatif dalam memasarkan produknya, salah satu caranya adalah dengan melakukan sebuah kegiatan promosi kepada masyarakat untuk menyampaikan keberadaan mengenai produk di pasar. Setiap produk yang dijual harus memiliki ciri khas produk sehingga dapat menarik perhatian pembeli. Penelitian ini bertujuan menganalisis data penjualan pada perusahaan GAIKINDO untuk mengetahui hal manakah diantara kategori, merk, spesifikasi dan lainnya yang menjadi alasan pembeli dalam membeli sebuah mobil di masa pandemi pada bulan Januari sampai bulan Desember tahun 2020. Selain itu, penelitian ini juga bertujuan untuk melakukan pemodelan data menggunakan data wholesales penjualan mobil yang didapatkan dari GAIKINDO pada bulan Januari 2020 sampai dengan Desember 2020. Serta untuk mempermudah pencarian informasi penjualan mobil berdasarkan spesifikasi, brand dan kategori - kategori lainnya. Dalam analisis data menggunakan beberapa teknik data modelling yaitu sitemap dan data flow diagram modeling untuk mendesain alur dari data yang akan dimodelkan.
\end{abstract}

Kata Kunci pemodelan data, DFD, penjualan, sitemap

\section{Pendahuluan}

Data modelling, menurut kebutuhannya merupakan bagian dari setiap tugas pemprosesan data, dan tidak terkecuali data warehouse [1]. Terdapat dua basis teknik dari data modelling yaitu entity-relationship (ER)) modelling dan dimensional modelling. ER modelling merupakan model yang sudah cukup lama digunakan untuk pemodelan basis data [2]. ER modelling adalah sebuah teknik dalam melakukan proses pendefinisian elemen data terhadap sistem perangkat lunak tertentu [1]. ER model ini sampai saat ini juga masih banyak yang digunakan. Selain ER modelling metode yang banyak dilakukan di dalam memproses data adalah dimensional modelling. Dimensional modelling merupakan salah satu teknik proses data yang mencangkup serangkaian metode, teknik dan konsep yang digunakan di dalam melakukan proses desain data warehouse. Dimensional modelling dapat juga diartikan sebagai teknik pemodelan untuk menyusun struktur dimensi dan matriks yang akan dianalisis

\footnotetext{
* Corresponding author.

(c) (i) Munir. S. A dkk.;

licensed under Creative Commons License CC-BY

ปnan210K2 Yayasan Lentera Dua Indonesia
} 
sepanjang dimensi [3]. Kedua teknik tersebut dapat diterapkan dalam memproses data bahkan sudah banyak perusahaan yang menggunakan teknik tersebut.

Salah satu penggunaan data modelling yaitu pada perusahaan GAIKINDO (Gabungan Industri Kendaraan Bermotor Indonesia ). GAIKINDO yang saat ini sudah tersebar luas di seluruh Indonesia. Di dalam melakukan maintenance data yang ada, pihak GAIKINDO melakukan proses data modelling yang saat ini disokong dengan adanya sumber laporan tahunan yang dapat dijadikan acuan dalam melakukan maintenance data tersebut. Laporan tahunan tersebut memberikan beberapa data-data mengenai hasil penjualan dari GAIKINDO itu sendiri. Data-data tersebut dapat dikategorikan sebagai Big Data. Big data dan analisisnya adalah pusat ilmu pengetahuan modern dan bisnis [4]. Sehingga dengan adanya big data di dalam pemprosesan data maka big data menjadi salah satu sektor penting yang dapat dijadikan sebagai acuan dalam menyelesaikan masalah yang ada pada perusahaan GAIKINDO.

Tujuan dari penelitian ini adalah berfokus dalam membuat suatu bentuk data modelling yang akan dipergunakan untuk menyelesaikan masalah pada sistem penjualan on sales yang akan dipergunakan untuk melihat mengenai karakteristik pembelian di suatu waktu. Pada kasus ini waktu yang dimaksud akan merujuk kepada kondisi pandemi Covid-19 yang sedang melanda di Indonesia sekaligus untuk mengetahui apa hal-hal yang menjadi alasan pembeli dalam membeli sebuah mobil di masa pandemi seperti kategori, merk dan spesifikasi pada bulan Januari sampai bulan Desember di tahun 2020. Sehingga dengan data tersebut penelitian ini dapat dipastikan dan dilihat sesuai kebutuhan produk GAIKINDO yang laku dan mudah terjual di dalam kondisi Covid-19, hasil dari penelitian ini semuanya akan merujuk kepada data yang diberikan oleh pihak GAIKINDO. Sehingga diharapkan bahawa pemodelan basis data sudah sesuai dengan kebutuhan yang ada di lapangan. Maka dari itu penelitian ini nantinya akan menggunakan beberapa tes menggunakan query dan constraint di dalam menjelaskan informasi dari data, yang mana nantinya diharapkan dapat membantu dalam memecahkan masalah yang menjadi fokus di penelitian ini.

\section{Metodologi}

Pada penelitian ini terdapat sebuah alur proses penelitian yang akan menjelaskan alur atau flow dari awal sampai akhir penelitian. Pada penelitian ini alur proses yang dilakukan memiliki tiga tahapan utama seperti yang tertampil dalam Gambar 1.

Tahap pertama yaitu studi literatur, tahapan ini dilakukan proses mengumpulkan bahan literatur yang digunakan dalam penelitian. Literatur dapat didapatkan dari website, jurnal terbuka dan artikel pendukung lainnya. Proses pengumpulan jurnal pendukung yang berkaitan dengan topik penelitian yang difokuskan. Mayoritas jurnal didapatkan melalui website sciencedirect dan google scholar dengan mempertimbangkan beberapa aspek dari tema, tahun terbit, volume terbit, dan tingkat kredibilitas dari jurnal yang dipilih.

Tahap kedua yaitu collecting atau pengumpulan data. Setelah dilakukan proses studi literatur maka dilanjutkan dengan proses pengumpulan data yang nantinya akan diolah dan diteliti sebagai objek utama penelitian, semua sumber data didapatkan dari proses studi literatur. Pada tahapan pengumpulan data ini dilakukan juga proses menentukan tujuan penelitian sehingga didapatkan data mentah. Pada penelitian ini dilakukan proses mengumpulkan data yang didapatkan melalui website dari GAKINDO, sehingga tingkat keakuratan data dapat dipertanggung jawabkan.

Tahap ketiga adalah analisis data, yakni tahapan proses analisis data yang sebelumnya telah didapatkan dari tahap pertama dan kedua. Pada tahap ini berfokus dalam pengolahan 


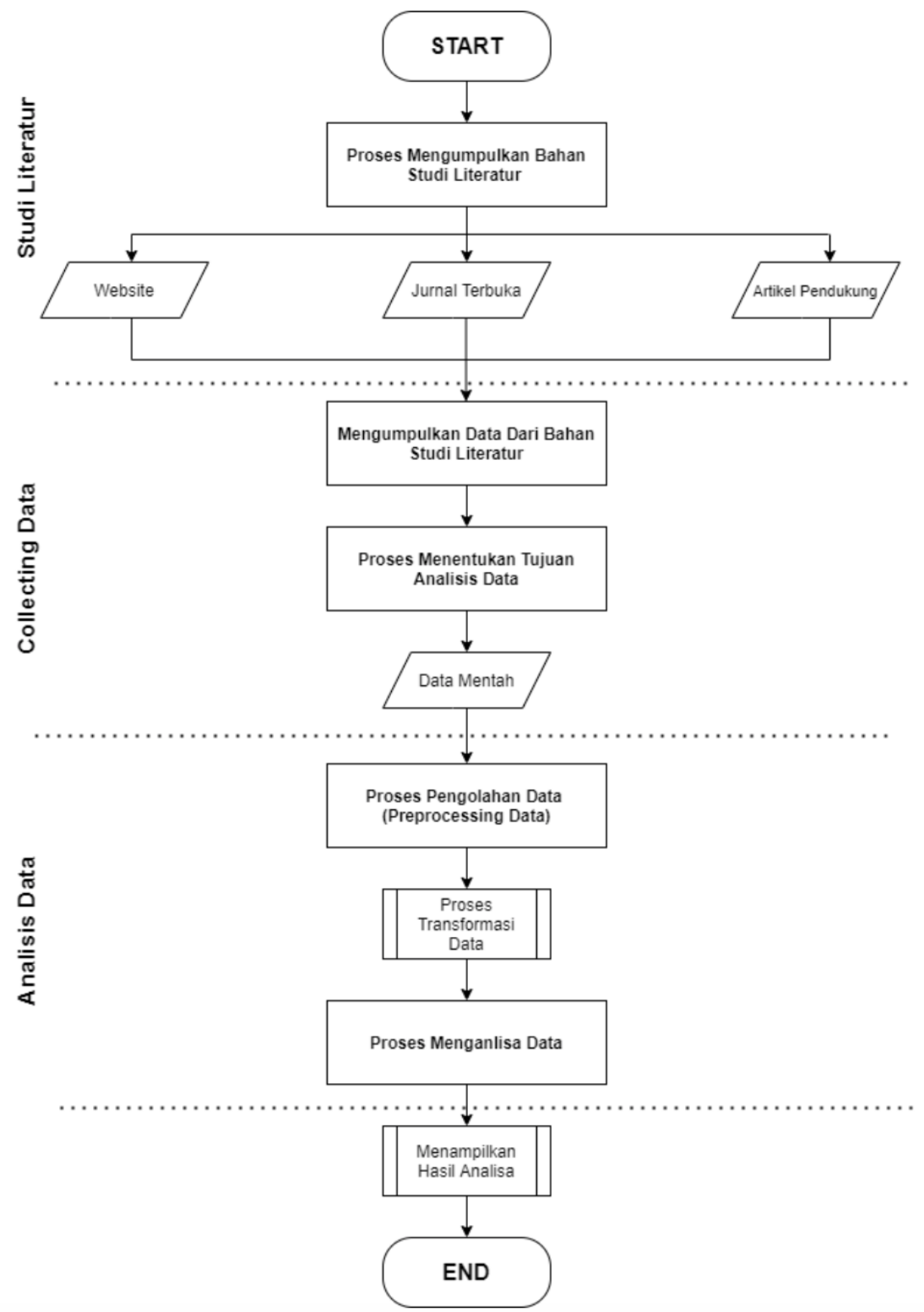

Gambar 1 Alur proses penelitian.

data (preprocessing data) berupa transformasi data sehingga data yang telah di transformasi mudah untuk dianalisis. Pada tahap analisis data, data yang sebelumnya telah didapatkan kemudian dilakukan proses pengolahan yang nantinya akan menggunakan beberapa tes menggunakan query dan constraint di dalam menjelaskan informasi dari data.

\section{Hasil dan pembahasan}

Sitemap dalam sebuah web digunakan sebagai panduan bagi pengunjung situs web yang ingin mengetahui struktur dan layanan yang disediakan dalam situs web. Sitemap adalah elemen desain interaktif yang mewakili struktur keseluruhan dari bagian media interaktif secara 
konkrit [5]. Navigasi web, salah satunya dengan sitemap merupakan bagian penting dalam suksesnya suatu web [6]. Walau demikian terdapat penelitian yang menyebutkan bahwa sebagian besar kategori situs web tidak terlalu peduli tentang penyediaan fitur sitemap [7]. Bahkan dari sitemap dapat digunakan untuk melakukan deteksi web bot [8].

Gambar 2 yang menunjukkan desain sitemap yang digunakan dalam Penelitian ini. Gambar 2 memiliki tiga menu utama yakni sistem home, search dan statistik. Kemudian dari masing-masing bagian menu terdapat submenu yang menyertainya, seperti menu statistik berisi dua submenu, terdiri dari jumlah model dan jumlah sales.

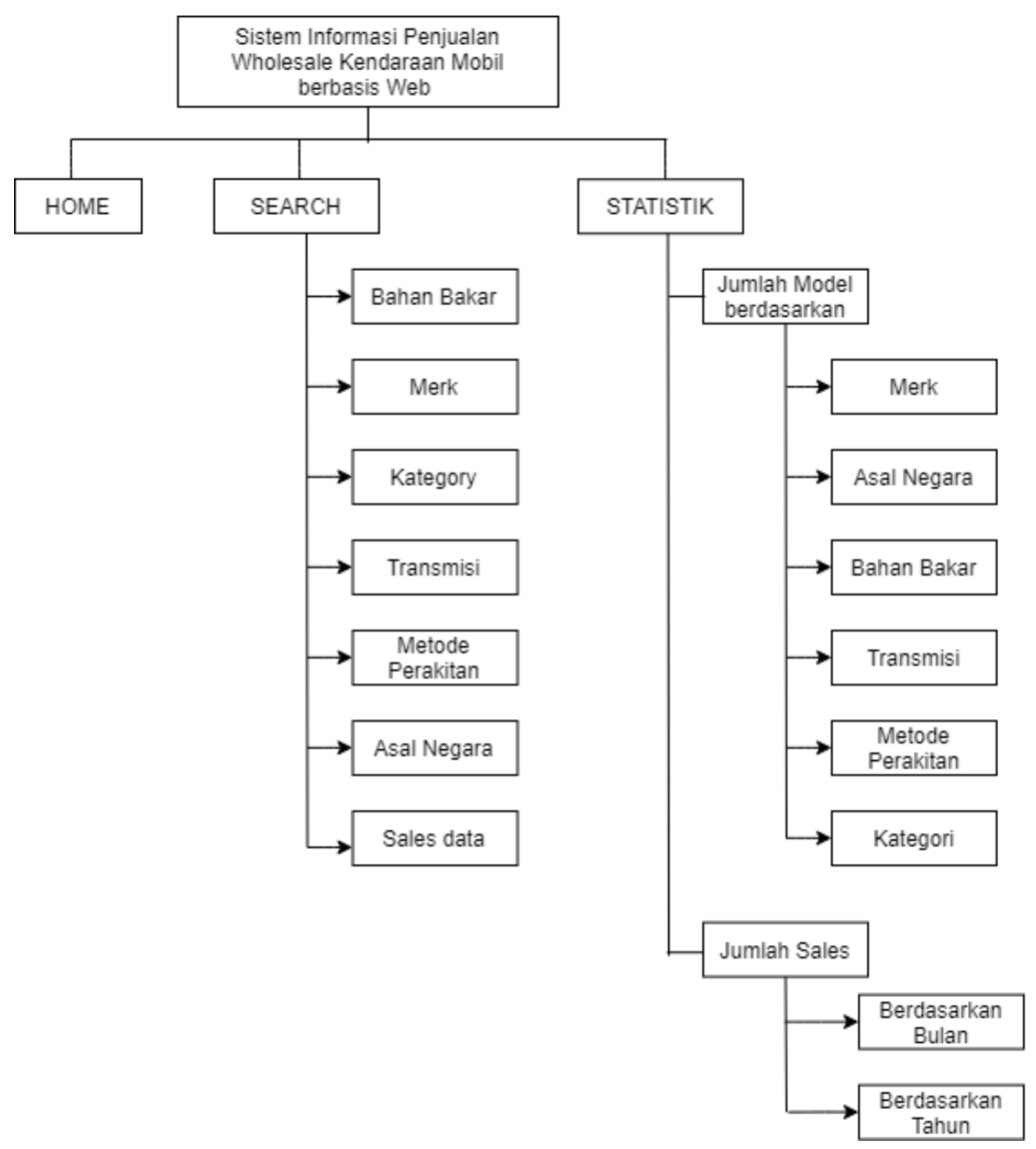

Gambar 2 Sitemap sistem informasi penjualan mobil.

Alur proses dalam sistem informasi dapat beragam dan dapat divisualkan seperti dengan data flow diagram (DFD). Gambar 3 merupakan DFD yang dipergunakan pada penelitian ini. DFD merupakan alat visual untuk menggambarkan model logika dan mengekspresikan transformasi data dari input ke output dalam suatu sistem [9]. DFD digambarkan menggunakan simbol untuk mewakili entitas, proses, aliran data, dan penyimpanan data yang berhubungan dengan sistem [10]. Perbandingan berbagai metode penggunaan berbagai diagram ini juga telah banyak dilakukan. Penggunaan DFD sebagai model formal untuk membangun sistem dapat digunakan oleh analis sistem [11].

Dalam DFD tersebut user untuk dapat menjalankan suatu proses maka perlu terlebih dahulu login dan memilih sesuai hak akses yang telah disepakati. Setelah user melakukan login akan ditampilkan tabel data yang telah dilengkapi dengan fungsi pencarian berdasarkan 


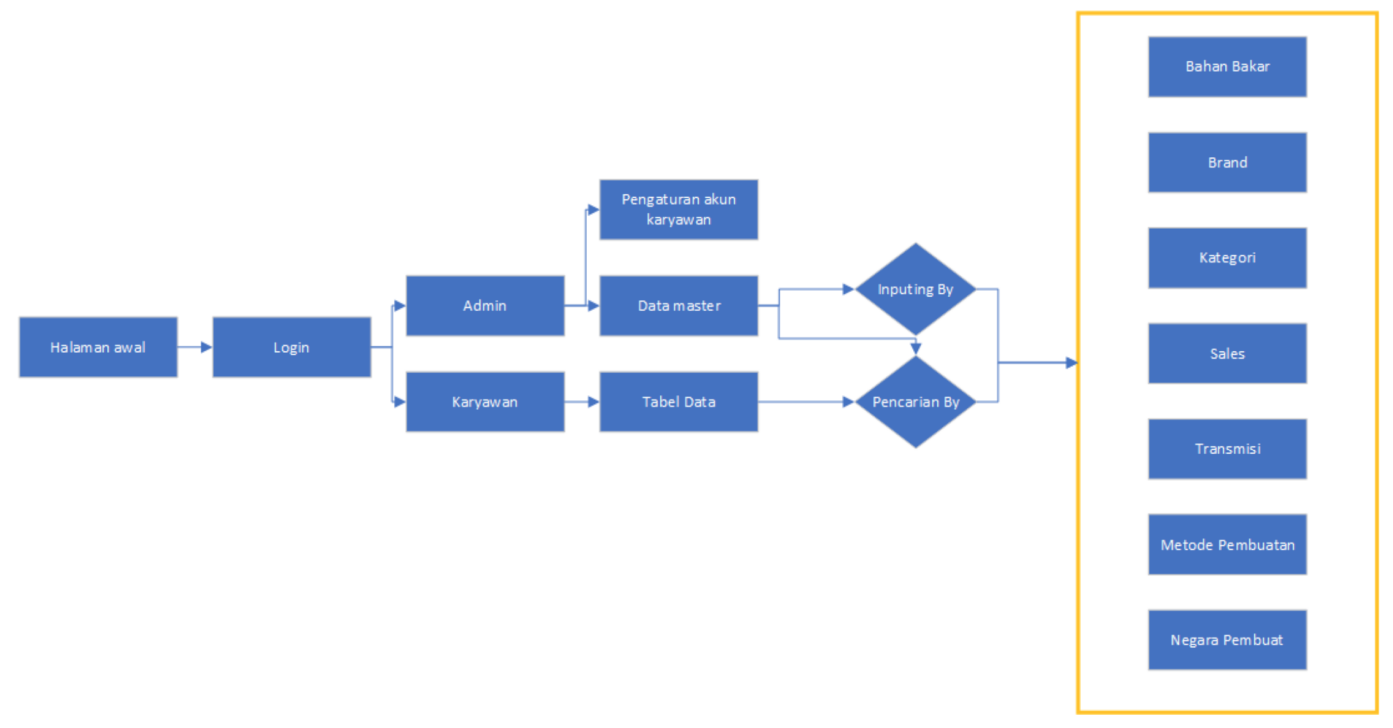

Gambar 3 DFD sistem informasi penjualan mobil.

beberapa tabel yang telah dibuat. Pada privilege admin terdapat beberapa fitur tambahan yaitu sebagai pengelola dari user manajemen karyawan serta sebagai user yang bertugas melakukan proses input master data yang telah diolah sebelumnya menggunakan program spreadsheet.

Basis data membutuhkan beberapa faktor atau kriteria yang harus dipertimbangkan saat melakukan desain atau perancangan. Kriteria tersebut antara lain, bagiamana efisisiensi basis data dapat dirancang. Efisiensi ini juga akan berkaitan dengan besarnya data yang disimpan, semakin kecil sebuah basis data maka semakin cepat pengoperasiannya. Salah satu ciri efisiensi dalam basis data adalah minimalnya terjadi redundansi. Optimalisasi redundansi juga dapat meningkatkan integritas data. Penyebaran data dalam banyak tabel akan menjadi minimal sehingga mengurangi data ambiguitas di semua tabel dalam basis data. Berdasarkan kriteria tersebut, desain basis data untuk penjualan wholesale mobil dalam penelitian ini adalah seperti dalam Gambar 4.

Untuk memastikan bahwa basis data yang dirancang sudah memenuhi kebutuhan dan memenuhi kategori basis data yang baik, dilakukan beberapa pengujian. Pegujian dilakukan dengan menggunakan perintah query dimana dalam prosesnya telah dilakukan proses memasukkan beberapa sampel data untuk pengujian. Adapun contoh dari perintah query yang digunakan dalam pengujian ini adalah seperti tertampil dalam Listing 1.

Listing 1 Pencarian nama model berdasarkan brand

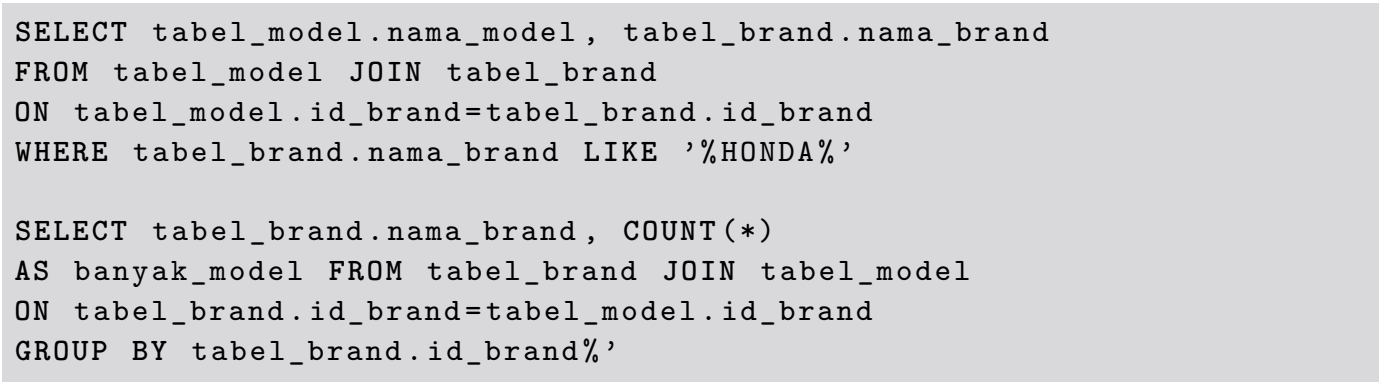




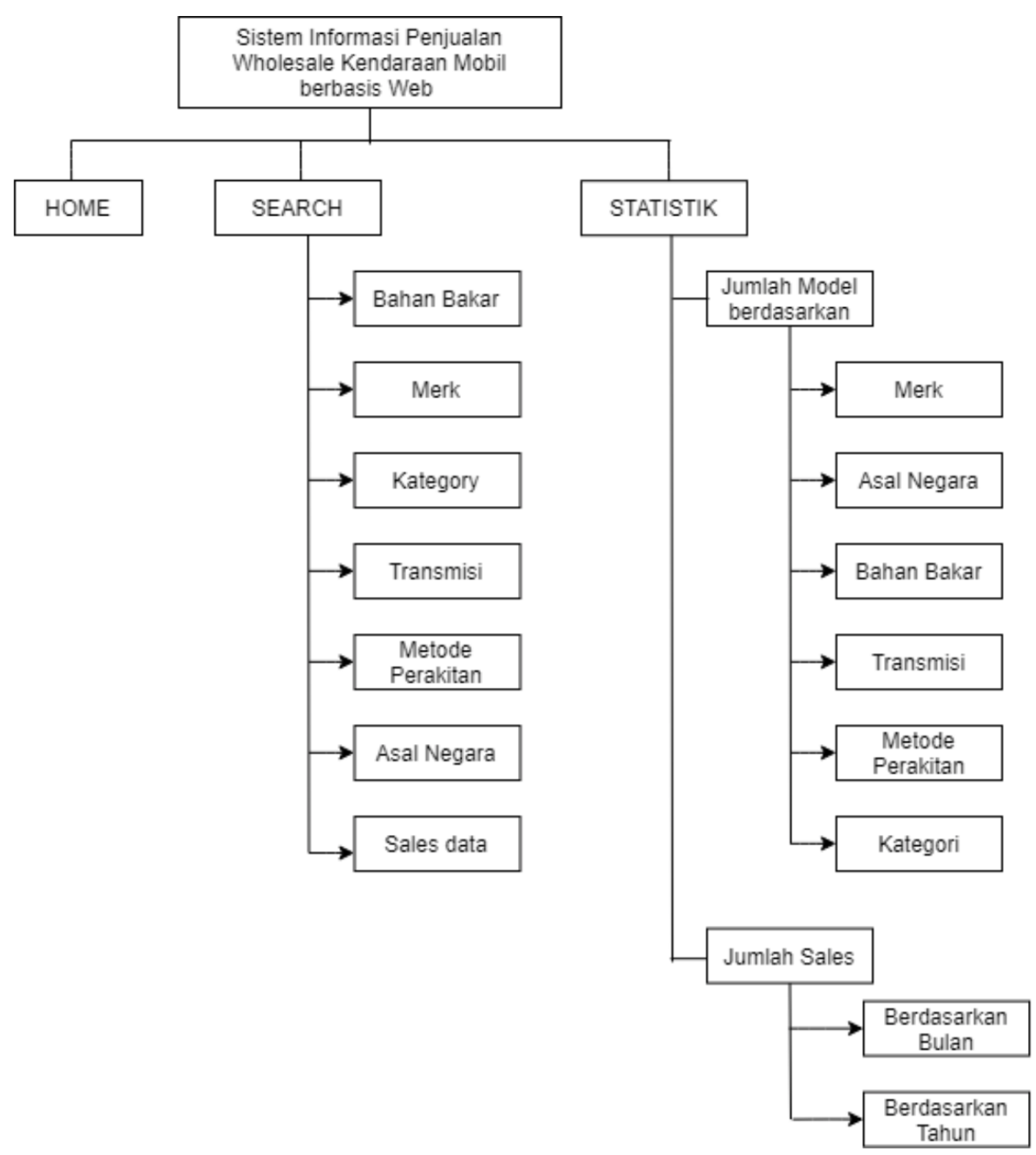

Gambar 4 Bagan desain basis data.

Listing 1 menghasilkan data model berdasarkan brand yang meliputi nama_model dan nama_brand serta data banyaknya model berdasarkan brand. Pencarian banyaknya model berdasarkan atas nama negara atau nama dan asal negara brand dapat juga dilakukan dengan melakukan query yang sesuai seperti yang tertampil dalam Listing2.

Listing 2 Pencarian nama model nama model beserta asal negara dan brandnya

SELECT tabel_model.nama_model, tabel_negara_asal.nama_negara_asal, tabel_brand.nama_brand FROM tabel_model JOIN tabel_negara_asal ON' tabel_model.id_negara_asal=tabel_negara_asal.id_negara JOIN tabel_brand $\mathrm{ON}_{\sqcup}$ tabel_model.id_brand=tabel_brand.id_brand

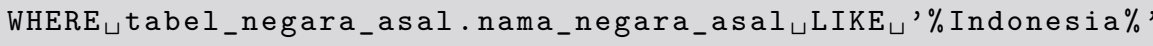

Pencarian yang lain dapat dilakukan sesuai dengan berbagai kriteria yang diharapkan denga melakukan query yang sesuai. Desain basis data yang dirancang dengan memperhatikan 
analisa kebutuhan sistem dapat membantu dalam hasil yang diharapkan.

\section{Kesimpulan}

Penelitian ini menghasilkan perancangan basis data untuk laporan penjualan mobil secara wholesale berdasarkan kriteria - kriteria yang ada. Rancangan dari basis data ini dapat digunakan untuk melihat model-model mobil berdasarkan brand, asal negara, transmisi dan lain-lain. Rancangan basis data yang didesain sesuai dengan kebutuhan akan mempermudah pencarian data berdasarkan kriteria-kriteria yang telah ditetapkan. Penggunaan data modelling seperti DFD banyak membantu dalam desain basis data dan pengembangan sistem secara keseluiruhan.

Pengetahuan query dangat dibutuhkan untuk bisa menghasilkan informasi yang diharapkan dari suatu basis data. Penelitian berikutnya diharapkan dapat mempertimbangkan besarnya cost dari masing-masing query sehingga perhitungan efisiensi dapat diberikan.

\section{Pustaka}

1 C. Ballard, D. Herreman, D. Schau, R. Bell, E. Kim, dan A. Valencic, Data modeling techniques for data warehousing. IBM Corporation International Technical Support Organization San Jose, 1998.

2 B. Thalheim, "The strength of er modeling," in Conceptual Modeling. Springer, 1999, pp. 227-242.

3 P. Ponniah, Data modeling fundamentals: a practical guide for IT professionals. John Wiley \& Sons, 2007.

4 S. Sagiroglu dan D. Sinanc, "Big data: A review," in 2013 international conference on collaboration technologies and systems (CTS). IEEE, 2013, pp. 42-47.

5 T. Garrand, Writing for multimedia and the Web: a practical guide to content development for interactive media. CRC Press, 2020.

6 C. Flavian, R. Gurrea, dan C. Orus, "Web design: a key factor for the website success," Journal of Systems and Information Technology, 2009.

7 J. Manhas, "Comparative study of website sitemap feature as design issue in various websites," IJEM-International Journal of Engineering and Manufacturing (IJEM), vol. 4, p. 22, 2014.

8 Y. Luo, G. She, P. Cheng, dan Y. Xiong, "Botgraph: Web bot detection based on sitemap," arXiv e-prints, pp. arXiv-1903, 2019.

9 H. Xiong, H. Zhang, X. Dong, L. Meng, dan W. Zhao, "Dfdvis: A visual analytics system for understanding the semantics of data flow diagram," in International Conference of Pioneering Computer Scientists, Engineers and Educators. Springer, 2017, pp. 660-673.

10 Q. Li dan Y.-L. Chen, "Data flow diagram," in Modeling and Analysis of Enterprise and Information Systems. Springer, 2009, pp. 85-97.

11 A. Y. Aleryani, "Comparative study between data flow diagram and use case diagram," International Journal of Scientific and Research Publications, vol. 6, no. 3, pp. 124-126, 2016. 